\title{
Contribution of low level HBV replication to continuing inflammatory activity in patients with anti-HBe positive chronic hepatitis $B$ virus infection
}

\author{
A S F LOK, S J HADZIYANNIS, I V D WELLER, M G KARVOUNTZIS, \\ J MONJARDINO, P KARAYIANNIS, L MONTANO, AND H C THOMAS

\begin{abstract}
From the Academic Department of Medicine, Royal Free Hospital, London, and Academic Department of Medicine, Hippokration General Hospital, Athens, Greece
\end{abstract}

SUMMARY The relationship between the histological diagnosis and serological and tissue markers of HBV replication in 41 Greek and 29 British patients with chronic HBV infection were studied. All the nine Greek and 13 British patients who were $\mathrm{HBeAg}$ positive had HBV-DNA in serum and HBcAg expression in the hepatocytes. The majority $(73 \%)$ of these patients had active liver disease. Forty seven per cent of the Greek and $19 \%$ of the British patients who were anti-HBe positive continued to display $\mathrm{HBcAg}$ in the liver with or without HBV-DNA detected in serum. All but three of these patients had persistently active liver disease. Continuing inflammatory activity in the liver, however, was also found in $31 \%$ of anti-HBe positive patients who had no evidence of HBV replication. In these patients, other factors such as delta agent, NANB viruses, alcohol abuse or an autoimmune reaction initiated by HBV may be contributory.

There are two phases of chronic HBV infection. In the earlier phase, the patients are $\mathrm{HBeAg}$ positive. They have active viral replication as evidenced by the presence of HBV-DNA in serum ${ }^{12}$ and hepatitis $\mathrm{B}$ core antigen ( $\mathrm{HBcAg})$ in the liver. ${ }^{3}$ These patients usually have active disease because of continuous immunological attack on hepatocytes which bear viral antigens. ${ }^{4-6}$ After a period of time, usually several years, viral replication ceases and the patients seroconvert from $\mathrm{HBeAg}$ to anti-HBe. ${ }^{78}$ During this latter phase, the continuous production of HBsAg protein ( $22 \mathrm{~nm}$ spheres) is maintained by hepatocytes containing integrated viral DNA. ${ }^{-12}$ In most patients, during this anti-HBe positive phase, there is a reduction in the inflammatory activity of the liver disease..$^{48}$ In some patients, however, the liver disease remains active. Recent reports have shown that a significant proportion of patients who are anti-HBe positive may have persistent viral replication with $\mathrm{HBV}$-DNA in serum and/or $\mathrm{HBcAg}$ in the liver. ${ }^{2}{ }^{1314}$ Such phenomena appear to be more common in patients of Mediterranean and Oriental origin and may account for continuing activity of liver disease in these patients ${ }^{15}$ (in

Address for correspondence: Dr H C Thomas. Academic Department of Medicine, Royal Free Hospital, Pond Street, London, NW3 2QG.

Received for publication 24 January 1984 preparation). Alternatively, persistently active liver disease may be unrelated to continuing $\mathrm{HBV}$ replication and other factors such as coexistent delta virus infection, alcohol abuse or autoimmune reaction may be contributory.

In this study, we have attempted to correlate the activity of liver disease with the level of $\mathrm{HBV}$ replication. We studied the relationship between the histological diagnosis and $\mathrm{HBeAg} /$ anti-HBe status and HBV-DNA in serum and the presence of $\mathrm{HBcAg}$ and delta antigen $(\delta \mathrm{Ag})$ in the liver in 41 Greek and 29 British patients with chronic HBV infection.

\section{Methods}

PATIENTS

Liver biopsies and serum samples from 32 Greek patients, referred to Hippokration General Hospital, Athens, and nine Greek and 29 British patients at The Royal Free Hospital, London, who had been HBsAg positive for more than one year, were studied. These patients were referred because of symptomatic liver disease or concern about infectivity. In some patients studied at the Royal Free Hospital, serial specimens were available.

Liver biopsy specimens were divided into two parts. One was embedded in OCT compound and 
immediately frozen in cold isopentane and the other was fixed in $10 \%$ formalin and processed for histological examination. Cryostat sections were cut from the frozen biopsies and examined for HBs, $\mathrm{HBc}$, and delta antigens $(\delta \mathrm{Ag})$ by direct immunofluorescence. Details of the methods have been described previously. ${ }^{16} 17$ The specificity of HBs, $\mathrm{HBc}$ and $\delta \mathrm{Ag}$ fluorescence was checked by absorption and blocking tests. All antisera used were also tested for non-specific staining in several control liver specimens obtained from HBsAg negative individuals. The amount of $\mathrm{HBcAg}$ in the liver was quantified by determining the percentage of hepatocyte nuclei positive for this antigen.

All serum samples were taken on the same day as or within 10 days of the liver biopsy, and were kept at $-20^{\circ} \mathrm{C}$ up to the time of serological testing. $\mathrm{HBsAg}, \mathrm{HBeAg}$ and anti-HBe were determined by radioimmunoassay (Abbott Laboratories). Sera were analysed for HBV-DNA sequences by molecular hybridisation using a ${ }^{32}$ P-labelled HBVDNA probe in the hybridot technique. This method can detect quantities of HBV-DNA as little as 0.05 pg.

\section{Results}

The serum $\mathrm{HBeAg} / \mathrm{anti}-\mathrm{HBe}$ status in relation to markers of HBV replication (serum HBV-DNA and hepatocyte display of $\mathrm{HBcAg}$ ) in the 41 Greek and 29 British patients studied are shown in Tables 1 and 2 .

\section{FORTY ONE GREEK PATIENTS}

Nine were $\mathrm{HBeAg}$ positive, 30 were anti-HBe positive and the remaining two were negative for both $\mathrm{HBeAg}$ and anti-HBe.

All the nine patients who were $\mathrm{HBeAg}$ positive had evidence of active viral replication with HBVDNA in serum and $\mathrm{HBcAg}$ in the liver. The majority (six), had chronic active hepatitis. The remaining patients had chronic persistent hepatitis

Table 1 Correlation of serum $\mathrm{HBeAg} /$ anti-HBe status to serum $H B V-D N A$ and $H B c A g$ in liver in 41 Greek patients with chronic $H B V$ infection

\begin{tabular}{|c|c|c|c|c|}
\hline & \multicolumn{2}{|c|}{$H B c A g+v e$} & \multicolumn{2}{|c|}{$H B c A g-v e$} \\
\hline & $\begin{array}{l}H B V- \\
D N A+\end{array}$ & $\begin{array}{l}H B V- \\
D N A-\end{array}$ & $\begin{array}{l}H B V- \\
D N A+\end{array}$ & $\begin{array}{l}H B V- \\
D N A-\end{array}$ \\
\hline $\mathrm{HBeAg}+$ /anti-HBe- (9) & 9 & 0 & 0 & 0 \\
\hline $\mathrm{HBeAg}-$ /anti-HBe + (30) & 8 & 6 & 0 & 16 \\
\hline $\mathrm{HBeAg}$-/anti-HBe- (2) & 0 & 0 & 0 & 2 \\
\hline All groups & 17 & 6 & 0 & 18 \\
\hline
\end{tabular}

Table 2 Correlation of serum HBeAg/anti-HBe status to serum $H B V$-DNA and $H B c A g$ in liver in 29 British patients with chronic $H B V$ infection

\begin{tabular}{|c|c|c|c|c|}
\hline & \multicolumn{2}{|c|}{$H B c A g+v e$} & \multicolumn{2}{|c|}{$H B c A g-v e$} \\
\hline & $\begin{array}{l}H B V- \\
D N A+\end{array}$ & $\begin{array}{l}H B V- \\
D N A-\end{array}$ & $\begin{array}{l}H B V- \\
D N A+\end{array}$ & $\begin{array}{l}H B V- \\
D N A-\end{array}$ \\
\hline $\mathrm{HBeAg}+/$ anti-HBe $-(13)$ & 13 & 0 & 0 & 0 \\
\hline $\mathrm{HBeAg}-$ /anti-HBe+ (16) & 0 & 2 & 1 & 13 \\
\hline All groups & 13 & 2 & 1 & 13 \\
\hline
\end{tabular}

(two) and active cirrhosis (one).

Among the 30 anti-HBe positive patients (Table 3), $14(47 \%)$ continued to display $\mathrm{HBcAg}$ in the hepatocytes, and eight of these also had HBV-DNA in the serum. Seventeen of these 30 patients $(57 \%)$ had active liver disease: chronic active hepatitis (16) and active cirrhosis (one). In 11 there was evidence of persistent $\mathrm{HBV}$ replication. Intrahepatic $\mathrm{HBcAg}$ was also detected in one of these 11 patients. In the

Table 3 Serological and tissue markers of $H B V$ replication in relation to histological diagnosis in 30 anti-HBe positive Greek patients

\begin{tabular}{|c|c|c|c|}
\hline $\begin{array}{l}\text { Patient } \\
\text { no }\end{array}$ & $\begin{array}{l}\text { Serum } \\
H B V-D N A\end{array}$ & $\begin{array}{l}H B c A g \\
\text { in liver }\end{array}$ & Histology \\
\hline 1 & - & + & Normal \\
\hline 2 & - & - & , \\
\hline 3 & - & - &, \\
\hline 4 & - & ++ & $\mathrm{CPH} \dagger$ \\
\hline 5 & - & - &, \\
\hline 6 & - & - & , \\
\hline 7 & - & - &, \\
\hline 8 & + & +++ & $\mathrm{CAH} \ddagger$ \\
\hline 9 & + & + & , , \\
\hline 10 & + & $++t$ & , \\
\hline 11 & + & +++ & , \\
\hline 12 & + & ++ & , \\
\hline 13 & + & ++ & , \\
\hline 14 & + & $+t$ & , \\
\hline $15^{*}$ & - & ++ & , \\
\hline 16 & - & ++ & , \\
\hline 17 & - & + & , \\
\hline 18 & - & - & , \\
\hline 19 & - & - & , \\
\hline 20 & - & - & , \\
\hline 21 & - & - & , \\
\hline 22 & - & - & , \\
\hline 23 & - & - &, \\
\hline 24 & + & + & Cirrhosis (active) \\
\hline 25 & - & - & ,, (inactive) \\
\hline 26 & - & - & (inactive) \\
\hline $27^{*}$ & - & +++ & HCC $\$$ \\
\hline 28 & - & - & , , \\
\hline 29 & - & - & , \\
\hline 30 & - & - & , \\
\hline
\end{tabular}


remaining six patients, however, continuing activity of the liver disease could not be accounted for by active HBV replication or delta infection. The 13 anti-HBe positive patients with inactive liver lesions had normal liver histology (three), chronic persistent hepatitis (four), inactive cirrhosis (two) or hepatocellular carcinoma (four). Three of these had $\mathrm{HBcAg}$ expression in the hepatocytes but serum HBV-DNA was not detectable.

Both patients who were $\mathrm{HBeAg}$ and anti-HBe negative were also negative for $\mathrm{HBcAg}$ in liver and HBV-DNA in serum. One had normal liver on biopsy and the other had chronic active hepatitis.

\section{TWENTY NINE BRITISH PATIENTS}

Thirteen were $\mathrm{HBeAg}$ and the remaining 16 anti$\mathrm{HBe}$ positive.

As with the Greek patients, all the $13 \mathrm{HBeAg}$ positive patients displayed $\mathrm{HBcAg}$ in the hepatocytes and HBV-DNA in their serum. The majority (nine), had chronic active hepatitis. The remaining four had chronic persistent hepatitis.

In contrast with the Greek patients, only three of the 16 anti-HBe positive patients had persistent HBV replication (Table 4). Two of these three patients (numbers 8 and 9) had seroconverted from $\mathrm{HBeAg}$ to anti-HBe three and five months before biopsy. The remaining patient (no 13) had $\mathrm{HBc}$ and $\delta \mathrm{Ag}$ detected in the hepatocytes but was negative for HBV-DNA in serum. Six of the 16 anti-HBe positive patients $(38 \%)$ continued to have active liver disease: chronic active hepatitis (five) and

Table 4 Serological and tissue markers of $H B V$ replication in relation to histological diagnosis in 16 anti-HBe positive British patients

\begin{tabular}{|c|c|c|c|}
\hline $\begin{array}{l}\text { Patient } \\
\text { no }\end{array}$ & $\begin{array}{l}\text { Serum } \\
H B V-D N A\end{array}$ & $\begin{array}{l}H B c A g \\
\text { in liver }\end{array}$ & Histology \\
\hline 1 & - & - & Normal \\
\hline 2 & - & - &, \\
\hline 3 & - & - & , \\
\hline 4 & - & - & $\mathrm{CPH}^{+}$ \\
\hline 5 & - & - & ,, \\
\hline 6 & - & - & , \\
\hline 7 & - & - & , \\
\hline 8 & + & - & $\mathrm{CAH} \ddagger$ \\
\hline 9 & - & + & ,, \\
\hline $10^{*}$ & - & - & , \\
\hline 11 & - & - &, \\
\hline 12 & - & - & , \\
\hline $13^{*}$ & - & + & Cirrhosis (active) \\
\hline 14 & - & - & ,, (inactive) \\
\hline 15 & - & - & , (inactive) \\
\hline 16 & - & - & ,, (inactive) \\
\hline
\end{tabular}

* Presence of intrahepatic $\delta \mathrm{Ag}$. + Chronic persistent hepatitis. $\ddagger$ Chronic active hepatitis. active cirrhosis (one). Three had evidence of HBV replication. Coexistent delta infection was also present in one of these three and another patient (no 10) in whom HBV replication was not detectable but no apparent cause was identified in the remaining two patients. The other 10 patients had inactive liver disease, either normal liver histology (three), chronic persistent hepatitis (four), or inactive cirrhosis (three). None of them showed any evidence of continuing HBV replication.

\section{DELTA INFECTION}

Intrahepatic $\delta \mathrm{Ag}$ was detected in two Greek and two British patients. All four patients were anti$\mathrm{HBe}$ positive, but three had $\mathrm{HBcAg}$ in their liver tissue. The histological diagnoses included chronic active hepatitis (two), active cirrhosis (one) and hepatocellular carcinoma (one).

\section{Discussion}

The HBeAg/anti-HBe status of a patient has been regarded as an indicator of the level of $\mathrm{HBV}$ replication and hence of relative infectivity. ${ }^{18} 19$ With the availability of the techniques of molecular hybridisation to detect HBV-DNA in serum, it has now been confirmed that HBV may continue to replicate after seroconversion from $\mathrm{HBeAg}$ to anti$\mathrm{HBe}^{2}{ }^{13}{ }^{14} \mathrm{HBc}$ antigen display in the liver may also reflect ongoing HBV replication in that it is usually present when HBV-DNA is present in the serum. ${ }^{20}$

In this study, we confirm that the presence of $\mathrm{HBeAg}$ is associated with evidence of active viral replication in both Greek and British patients. In addition, $47 \%$ of anti-HBe positive Greek patients exhibited $\mathrm{HBcAg}$ in the liver with or without detectable HBV-DNA in the serum. In contrast, only three (19\%) of 15 anti-HBe positive British patients, had evidence of continuing HBV replication. In two of these, the liver biopsies had been taken within six months of $\mathrm{HBe} \mathrm{Ag} / \mathrm{anti}-\mathrm{HBe}$ seroconversion, and in the remaining patient there was coexistent delta infection. In the Greek patients serial specimens were not available so that the relationship of a particular serological pattern to $\mathrm{HBe}$ antigen/antibody seroconversion could not be determined. These patients were, however, similar to the British patients in that they had been referred to a hepatology service with symptomatic liver disease.

The explanation for the difference in the prevalence of low level HBV replication in the two populations of anti-HBe positive patients is not clear. Recent evidence suggests that clearance of hepatocytes supporting HBV replication is dependent on an immune response to $\mathrm{HBc}$ 
antigen $^{321}$ whereas clearance of $\mathrm{HBe}$ antigen is related to an independent immune response to the determinants on this soluble protein. It is possible that both of these responses are independently genetically determined and in Greek patients the immune response to and the clearance of $\mathrm{HBe}$ antigen is more efficient than in British patients. Alternatively, the cell mediated response to $\mathrm{HBc}$ antigen displayed on the surface of hepatocytes supporting HBV replication may be less effective in Greek than British patients. The restricted number of epitopes displayed on $\mathrm{HBe}$ antigen - two identified by murine monoclonal antibodies ${ }^{22}$ make it likely that very few immune response genes control the clearance of this antigen and therefore large differences may occur between different populations. Elimination of $\mathrm{HBV}$ infected hepatocytes probably depends on the recognition of viral antigens in association with HLA class 1 proteins by cytotoxic T lymphocytes. ${ }^{23}$ It is possible that certain HLA types present in the Greek population may not associate as well as others with the HBV antigens leading to relative failure of immune lysis of infected hepatocytes. ${ }^{24}$ This has been reported in influenza. ${ }^{25}$ Thus, there are reasons to suggest that genetic factors may determine the difference between the Greek and British patients. Other factors may also be important. Unlike the British patients, most of the Greek patients were not studied serially and it remains possible that some of those who continued to replicate $\mathrm{HBV}$ during the anti-HBe phase, may have been biopsied near to seroconversion from $\mathrm{HBeAg}$ to anti-HBe, as was the case with the British patients. Finally, the time of infection may also determine the efficiency of the various components of the immune system. It is likely that the Greek patients are infected early in life, whereas the British patients acquire the infection in adulthood.

It has been suggested that inflammatory liver disease is associated with viral replication. ${ }^{4}$ Although the majority $(68 \%)$ of $\mathrm{HBeAg}$ positive patients had active liver lesions on biopsy, $57 \%$ of Greek and $38 \%$ of British patients who were anti-HBe positive also had chronic active hepatitis or active cirrhosis. Fourteen of these 23 anti-HBe positive patients with active inflammatory liver disease also had persistent HBV replication showed by the presence of $\mathrm{HBcAg}$ in the liver or HBVDNA in serum. The remaining nine patients, however, continued to have active liver disease in the absence of detectable HBV replication. Delta infection accounted for persistent inflammatory activity in only one of these patients. While it is possible that HBV replication continues below the levels of detection, other factors should be considered. Coexistent NANB hepatitis or alcohol abuse may contribute to the active liver disease in some of these patients. An alternative explanation could be a perpetuation of an autoimmune reaction against liver membrane antigens, initiated during and against liver membrane antigens, and persisting after cessation of HBV replication. ${ }^{4}$ In support of this, liver membrane antibodies have been detected in some patients with chronic HBV infection. ${ }^{26}$ Thus, although low level HBV replication, identified by the presence of HBV-DNA in serum or $\mathrm{HBc}$ antigen in the liver, may explain the continuing inflammatory activity in some anti-HBe positive patients, there is a large proportion in whom this is not the case and other factors may be contributory.

ASFL is supported by the University of Hong Kong.

\section{References}

1 Weller IVD, Fowler MJF, Monjardino J et al. The detection of HBV-DNA in serum by molecular hybridisation: a more sensitive method for detection of complete HBV particles. J Med Virol 1982; 9: 273-80.

2 Bonino F, Hoyer B, Nelson J et al. Hepatitis B virus DNA in the sera of HBsAg carriers: a marker of active hepatitis B virus replication in the liver. Hepatology 1981; 1: 386-91.

3 Gudat F, Bianchi L, Sonnabend W, Theil G, Aenishaenslin W, Stalder GA. Pattern of core and surface expression in liver tissue reflects state of specific immune response in hepatitis B. Lab Invest 1975; 32: 1-5.

4 Thomas HC, Montano L, Goodall A, deKoning R, Oladapo J, Wiedmann KH. Immunological mechanisms in chronic hepatitis B infection. Hepatology 1982; 2: 116S-21S.

5 Eddleston ALWF, Williams R. Inadequate antibody response to HBV or suppressor $\mathrm{T}$ cell defect in development of active chronic hepatitis. Lancet 1974; 2: 1543-5.

6 Dudley FJ, Fox RA, Sherlock S. Cellular immunity and hepatitis-associated, Australia antigen liver disease. Lancet 1972; 1: 723-6.

7 Realdi G, Alberti A, Ruzzi M et al. Seroconversion from $\mathrm{HBe}$ antigen to anti-HBe in chronic HBV infection. Gastroenterology 1980; 79: 195-9.

8 Hoofnagle J, Dusheiko GM, Seeff LB. Seroconversion from hepatitis B e antigen to antibody in chronic type B hepatitis. Ann Intern Med 1981; 94: 744-8.

9 Hirschman SZ. Integration enzyme hypothesis for replication of hepatitis B virus. Lancet 1975; 2: 436-8.

10 Fowler MJF, Monjardino J, Weller IVD, Lok ASF, Thomas HC. An analysis of the molecular state of HBV-DNA in the liver and serum of patients with 
chronic hepatitis or primary liver cell carcinoma and the effects of therapy with adenine arabinoside monophosphate. Gut 1984; 25: 611-8.

11 Brechot C, Hadchovel M, Scotto J et al. Detection of hepatitis B virus DNA in liver and serum: a direct appraisal of the chronic carrier state. Lancet 1981; 2: 765-7.

12 Shafritz DA, Shouval D, Shermon HI et al. Integration of hepatitis B virus DNA into the genome of liver cells in chronic liver disease and hepatocellular carcinoma. N Engl J Med 1981; 305: 1067-73.

13 Scotto J, Hadchovel M, Hery C, Yvart J, Tiollais P, Brechot C. Detection of hepatitis B virus DNA in serum by a simple spot hybridisation technique: comparison with results for other viral markers. Hepatology 1983; 3: 279-84.

14 Lieberman HM, LaBrecque DR, Kew MC, Hadziyannis SJ, Shafritz DA. Detection of hepatitis B virus DNA directly in human serum by a simplified molecular hybridisation test: comparison to $\mathrm{HBeAg} /$ anti-HBe status in HBsAg carriers. Hepatology 1983; 3: $285-91$.

15 Sherlock S, Thomas HC. Hepatitis B virus infection: the impact of molecular biology. Hepatology 1983; 3: 455-6.

16 Hadziyannis S, Gerber MA, Vissoulis C, Popper H. Cytoplasmic hepatitis B antigen in 'ground glass' hepatocytes of carriers. Arch Pathol 1973; 96: 327-35.

17 Montano L, Miescher GC, Goodall AH, Janossy G, Thomas HC. Hepatitis B virus and HLA antigen display in the liver during chronic hepatitis B virus infection. Hepatology 1982; 2: 557-61.

18 Okada K, Kamiyama I, Inomata $\mathrm{M}$ et al. $\mathrm{E}$ antigen and anti-e in the plasma of asymptomatic carrier mothers as indicators of positive and negative transmission of hepatitis B virus to their infants. N Engl J Med 1976; 294: 746-9.

19 Alter JH, Seeff LB, Kaplan PM et al. Type B hepatitis: The infectivity of blood positive for $\mathrm{HBe}$ antigen and DNA polymerase after accidental needlestick exposure. $N$ Engl J Med 1976; 295: 909-13.

20 Hadziyannis SJ, Lieberman HM, Karvountzes GG, Shafritz DA. Analysis of liver disease, nuclear $\mathrm{HBcAg}$, viral replication, and hepatitis $B$ virus DNA in liver and serum of $\mathrm{HBeAg}$ versus Anti-HBe positive carriers of hepatitis B virus. Hepatology 1983; 3: 656-62.

21 Eddleston ALWF, Mondelli M, Mieli-Vergani G, Williams R. Lymphocyte cytotoxicity to autologous hepatocytes in chronic hepatitis $B$ virus infection. Hepatology 1982 suppl; 2: 122-7S.

22 Takahashi K, Machida A, Funatsu G et al. Immunochemical structure of hepatitis $B$ e antigen in the serum. J Immunol 1983; 130: 2903-7.

23 Doherty PC, Zinkernagel RM. A biological role for major histocompatibility antigens. Lancet 1975; 1: 1406-9.

24 Thomas HC, Lok ASF. The immunopathology of autoimmune and hepatitis $B$ virus induced chronic hepatitis. Sem Liver Dis 1984; 4: 36-46.

25 McMichael A. HLA restriction on human cytotoxic T lymphocyte specific for influenza virus. Poor recognition of virus associated with HLA AZ. J Exp Med 1978; 148: 1458-67.

26 Wiedmann KH, Bartholomew TC, Brown DJC, Thomas HC. Liver membrane antibodies detected by immunoradiometric assay in acute and chronic virus induced and autoimmune liver disease. Hepatology 1984; 4: 199-204. 